\title{
A opção preferencial pelos pobres em Santa
}

\section{Dulce dos Pobres}

\author{
The preferential option for the poor in Saint Dulce of the Poor
}

Edilmar CARDoso Ribeiro(iDa

\section{Resumo}

Santa Dulce dos Pobres (1914-1992), ao longo de sua vida, deu início, desenvolveu e sustentou um intenso apostolado social de total dedicação aos pobres, deixando um legado que constitui um dos maiores complexos filantrópicos sociais do Brasil. O objetivo deste artigo é examinar a opção preferencial pelos pobres em Santa Dulce. Por meio de um estudo qualitativo e bibliográfico, o trabalho apresenta a opção preferencial pelos pobres de Santa Dulce como uma radical experiência de amor e serviço, de solidariedade e fraternidade para com os mais necessitados; explica como a opção de Santa Dulce ilumina e é estimulada pela opção preferencial pelos pobres do Episcopado Latino-Americano nas Conferência Gerais de Medellín (1968), de Puebla (1979), de Santo Domingo (1992) e de Aparecida (2007); esclarece como a opção de Santa Dulce se fundamenta no amor a Cristo sofredor, presente no rosto do pobre, o outro Cristo; e, por fim, propõe Santa Dulce como a boa samaritana da Bahia.

Palavras-chave: Santa Dulce dos Pobres. Irmã Dulce. Opção preferencial pelos pobres. Amar e servir.

\section{Abstract}

Throughout her life, Saint Dulce of the Poor (1914-1992) began, developed, and sustained an intense social apostolate of total dedication to the poor, leaving a legacy that constitutes

\footnotetext{
a Pontifícia Universidad Católica de Chile (PUC-Chile), Santiago, Chile. Doutor em História da Igreja, e-mail: edilmar.cardoso@uc.cl
} 
one of the most outstanding social, philanthropic complexes in Brazil. The purpose of this article is to examine the preferential option for the poor in Santa Dulce. Through a qualitative and bibliographic study, the work presents the preferential option for the poor of Santa Dulce as a radical experience of love and service, of solidarity and fraternity towards the neediest; explains how the option of Saint Dulce illuminates and is stimulated by the preferential option for the poor of the Latin American Episcopate in the General Conferences of Medellín (1968), Puebla (1979), Santo Domingo (1992) and Aparecida (2007; clarifies how the option of Sister Dulce is based on the love of the suffering Christ, present in the face of the poor, the other Christ; and, finally, proposes Santa Dulce as the good Samaritan woman from Bahia.

Keywords: Saint Dulce of the Poor. Sister Dulce. Preferential option for the poor. To love and to serve.

\section{Introdução}

Com o processo de beatificação e canonização de Irmã Dulce, alguns estudos sobre sua vida e seu apostolado foram publicados, mas os trabalhos que exploram aspectos da opção preferencial pelos pobres em Santa Dulce, relacionando-os com a tradição eclesial, ainda são raros. Este artigo, portanto, busca examinar a opção preferencial pelos pobres em Santa Dulce, expressada em sua espiritualidade e apostolado, relacionando-a com os ensinamentos das Conferências Gerais do Episcopado Latino-Americano e do Caribe, celebradas em Medellín-Colômbia (1968), em Puebla-México (1979), em Santo DomingoRepública Dominicana (1992) e em Aparecida-Brasil (2007), com o pensamento de João Crisóstomo sobre os pobres e com a parábola do bom samaritano (LC 10, 25-37).

Em termos metodológicos, a pesquisa caracterizou-se por um estudo qualitativo e bibliográfico, que se debruçou sobre os escritos já publicados sobre Santa Dulce dos Pobres, sobre os documentos conclusivos das Conferências Gerais do Episcopado Latino-Americano e do Caribe, sobre o Comentário ao Evangelho de São Mateus de João Crisóstomo e sobre a parábola bíblica do bom samaritano (LC 10, 25-37).

Quem foi Santa Dulce dos Pobres? Qual a origem do interesse e preocupação pelos pobres da santa baiana? O que significou e implicou a opção 
preferencial pelos pobres na vida de Santa Dulce? Como a opção preferencial pelos pobres expressou-se na espiritualidade e no apostolado de Santa Dulce? Qual a relação da opção preferencial pelos pobres em Santa Dulce com a tradição eclesial Latino-Americana? Estas são as questões que no desenvolver deste trabalho iremos responder.

Para tanto, primeiro apresentamos alguns elementos biográficos essenciais de Irmã Dulce, assim como indicaremos seus principais empreendimentos sociais e o legado atual das Obras Sociais Irmã Dulce. Em seguida, a partir da noção de opção preferencial pelos pobres presente nos documentos conclusivos das Conferências Gerais do Episcopado LatinoAmericano e do Caribe, analisaremos a opção preferencial pelos pobres em Santa Dulce e como esta opção se expressou em sua espiritualidade e apostolado, através do seu ideal amar e servir, de uma mística do Cristo presente no rosto do pobre e de uma aproximação entre Santa Dulce e o bom samaritano (LC 10, 2537). Por fim, propomos algumas provocações e ensinamentos que ainda hoje podemos tirar da opção preferencial pelos pobres em Santa Dulce.

\section{Irmã Dulce e seu legado}

Maria Rita de Souza Brito Lopes Pontes, segunda filha de Augusto Lopes Pontes e Dulce Maria de Sousa Brito Lopes Pontes, nasceu em Salvador, capital do Estado da Bahia, em 26 de maio de 1914. Em 8 de fevereiro de 1933, Maria Rita entrou na Congregação das Irmãs Missionárias da Imaculada Conceição da Mãe de Deus ${ }^{1}$, na cidade de São Cristóvão, Estado de Sergipe, Brasil, e em 13 de agosto deste mesmo ano recebeu o hábito de freira, adotando o nome de Irmã Dulce, em homenagem a sua mãe que morrera quando ela tinha 7 anos (ROCHA, 2019, p. 35).

\footnotetext{
${ }^{1}$ A Congregação das Irmãs Missionárias da Imaculada Conceição da Mãe de Deus foi fundada em 1910, em Santarém, Pará, por Dom Amando Bahlmann, dos Frades Menores Franciscanos, e Madre Imaculada Tombrok (PASSARELLI, 2019, p. 32). 
Após a consagração como freira, em 1934, Irmã Dulce foi destinada a desenvolver seu apostolado em sua própria cidade natal, Salvador, onde praticamente gastara toda sua existência no apostolado religioso e social. Nos primeiros quatro meses ela trabalhou no Hospital Espanhol, onde fazia um pouco de tudo: auxiliar de enfermagem, porteira e sacristã. Foi depois destinada a ensinar em um colégio mantido por sua Congregação Religiosa no bairro Massaranduba. A experiência como professora não lhe saiu muito bem, até porque seu pensamento estava voltado para o trabalho de assistência aos pobres e por isso foi deixada livre para dedicar-se a este apostolado social (PASSARELLI, 2019, p. 55-64).

Em 1935, a religiosa baiana começou a dar assistência à comunidade pobre do bairro de Alagados, atendendo as necessidades espirituais e materiais dos operários. Neste mesmo bairro, Irmã Dulce criou um posto médico em 1937. Junto com Frei Hildebrando Kruthaup (1902-1986)2, fundou a União Operária São Francisco, para a assistência social dos operários, cujo nome um ano depois mudou para Círculo Operário da Bahia (COB). No bairro de Massaranduba, Irmã Dulce fundou o colégio Santo Antônio, cuja escola tinha como objetivo atender os operários e seus filhos (PASSARELLI, 2019, p. 75-83).

Em 1939, interpelada por crianças e idosos doentes sem assistência e abandonados pelas ruas de Salvador, Irmã Dulce sentiu-se tocada e na obrigação de ajudá-los. Sem ter onde colocá-los, a freira invadiu várias casas abandonadas para abrigar os doentes. Ela foi expulsa dos lugares invadidos e por um período aproximadamente de dez anos perambulou de um lugar a outros com seus doentes até ocupar, com a autorização da superiora da comunidade religiosa da qual ela fazia parte, o galinheiro do Convento Santo Antônio, onde se estabeleceu com 70 doentes. Deste modo, de um galinheiro, Irmã Dulce fundou o Albergue Santo Antônio para os doentes, crianças e adolescentes recolhidos nas ruas. Devido à necessidade de separar os doentes das crianças e jovens, foi construído o Educandário Santo Antônio em Simões Filhos, cidade há 23 quilômetros de

\footnotetext{
2 Hildebrando Kruthaup, frei franciscano alemão, chegou no Brasil em 1924 ainda como seminarista (ROCHA, 2019, p. 33-35).
} 
Salvador. Do Albergue Santo Antônio surgiu o Hospital Santo Antônio, que transformou-se em um dos maiores hospitais da Bahia. Estes empreendimentos sociais foram iniciados, desenvolvidos e consolidados por Irmã Dulce com muito trabalho, sacrifícios e coragem, tornando-se ao longo dos anos um dos maiores e mais respeitáveis complexos filantrópicos do Brasil: As Obras Sociais Irmã Dulce (OSID) (ROCHA, 2019, p. 88-90; 108).

Irmã Dulce morreu aos 77 anos no Convento Santo Antônio, em 13 de março de 1992. Sua saúde frágil não a impediu de realizar uma árdua atividade social em defesa e cuidado da vida dos mais necessitados, excluídos e marginalizados. Ainda em vida, a freira baiana já era aclamada pelo povo baiano como santa, como mãe dos pobres e como o anjo bom da Bahia (ROCHA, 2019, p. 189-195).

Em janeiro de 2000 deu-se início ao processo de canonização de Irmã Dulce. Em abril de 2009, o Papa Bento XVI Ihe concedeu o título de Venerável, isto é, reconheceu que ela viveu em grau heroico as virtudes cristãs da Fé, Esperança e Caridade (PASSARELLI, 2019, p. 221). A beatificação ocorreu em outubro de 2010, depois que a Congregação para a Causa dos Santos reconheceu a autenticidade do primeiro milagre ${ }^{3}$ atribuído à Venerável Irmã Dulce. Este primeiro milagre aconteceu na cidade de Itabaiana, no Estado de Sergipe, quando Claúdia Cristina dos Santos foi curada de uma grave hemorragia após dar à luz seu segundo filho (ROCHA, 2019, p. 212-220). O reconhecimento deste milagre transformou a Venerável Dulce em Beata. A Cerimônia de Beatificação ocorreu em Salvador, em 22 de maio de 2011, na qual a freira passou a ser chamada com o título de Bem-Aventurada Dulce dos Pobres (PASSARELLI, 2019, p. 222-223).

\footnotetext{
${ }^{3}$ Nos processos de beatificação e canonização, os eventuais milagres passam por três etapas de avaliação: uma avaliação realizada por peritos médicos (que dão o aval científico); uma avaliação realizada por teólogos; e a aprovação final do colégio cardinalício. Uma graça só é considerada milagre se atende a quatro requisitos básicos: a intensidade, ou seja, alcançada logo após a petição; a perfeição, isto é, que atenda e garanta de modo completo o pedido; a durabilidade e permanência do benefício e seu caráter preternatural, ou seja, que a ciência não consiga explicá-lo (MARIA, 2019, p. 7).
} 
O segundo milagre atribuído à intercessão da Beata Dulce dos Pobres foi reconhecido pelo Papa Francisco em 13 de maio de 2019. O agraciado pelo milagre foi José Maurício Bragança Moreira, natural de Salvador e morador em Recife, totalmente cego por mais de 14 anos por causa de um glaucoma (ROCHA, 2019, p. 221-224). Com este segundo milagre completava-se a última etapa do processo de canonização da beata baiana, cuja canonização ocorreu em 13 de outubro de 2019. A partir de então, ela passou a ser chamada de Santa Dulce dos Pobres. Ela é a primeira santa nascida no Brasil (PASSARELLI, 2019, p. 223).

As Obras Sociais Irmã Dulce são hoje para o Brasil o maior legado deixado por Santa Dulce dos Pobres. É importante ressaltar que toda forma de assistência atualmente fornecida pelas Obras Sociais Irmã Dulce é gratuita. As Obras dispõem de um laboratório de informática educativa para pessoas com deficiência grave, 1.237 leitos e cerca de 130 residentes e internos de Medicina. Anualmente são realizados mais de quatro milhões de atendimentos: mais de 500 mil consultas gerais de ambulatórios; cerca de 9.500 intervenções cirúrgicas; cerca de 20 mil intervenções de ambulatório em pessoas com deficiência; mais de 140 mil consultas de ambulatório (ginecologia); cerca de 50 mil consultas de ambulatório (geriatria); quase 300 mil consultas de ambulatório (fisioterapia); cerca de 760 mil exames de laboratório; e aproximadamente 80 mil exames de bioimagem. Atuam cerca de 200 voluntários e mais de três mil colaboradores (PASSARELLI, 2019, p. 225-226).

Este legado é fruto do amor, trabalho e dedicação de uma simples mulher, frágil de saúde, mas uma pessoa forte e corajosa, que encontrou no serviço ao pobre o sentido de sua existência.

\section{A opção preferencial pelos pobres nas Conferências do Episcopado Latino-Americano e do Caribe (Celam) e em Santa Dulce}

Ó mundo tão desigual, tudo é tão desigual, ô ô ô ô ô.

De um lado este carnaval, de outro a fome total, ô ô ô ô ô (GILBERTO GIL; HERBERT

VIANNA; JOÃO BARONE, A novidade [música], 1986). 
O apostolado de Irmã Dulce se coloca em um quadro histórico, social e político bastante difícil para o Brasil e para a América Latina em geral. Foi um período marcado por graves problemas sociais e pela instauração das ditaduras militares, que no Brasil reinou entre 1964 e 1985.

A explosão demográfica nas cidades somado ao fenômeno do êxodo rural fez com que as cidades crescessem na América Latina - nem sempre de forma ordenada, planejada e apropriadamente habitável. A falta de moradia adequada, saneamento básico, trabalho digno, transporte eficiente causaram verdadeiros dramas sociais. No campo, o latifúndio tomou conta incentivado por políticas inspiradas no Breton Woods. Nestes anos, cabe ressaltar ainda, os governos de muitos países latinos foram tomados por militares (BRUNELLI, 1986, p. 37).

Neste contexto, houve um forte incremento da pobreza: desempregados, crianças, jovens e idosos doentes sem assistência vivendo em situação de rua nos grandes centros urbanos, como por exemplo, Salvador. A miséria era gritante (PASSARELLI, 2019, p. 55-57).

No contexto eclesial, as orientações no âmbito social eram dadas pelas encíclicas Rerum novarum (1891) e a Quadragesimo Anno (1931). A primeira, do Papa Leão XIII, inaugurou a doutrina social da Igreja Católica, e tem como ensinamento fundamental quatro pontos: afirma o direito natural de propriedade privada, mas ressalta sua função social; atribui ao Estado o dever de intervir diante dos problemas econômico-sociais, especialmente em defesa dos pobres, mas também coloca limites à ação estatal, que deve ter sempre um caráter supletivo; lembra aos operários seus deveres em relação aos empresários, mas também sublinha que os operários têm o direito a um salário suficiente para garantir um teor de vida humana; e condena a luta de classe, mas reconhece aos operários o direito de se reunirem para defender seus direitos (associacionismo operário). É uma encíclica que buscava dar respostas a partir do ocular cristão à questão social causada pela Revolução Industrial e pelas doutrinas do liberalismo econômico, assim como pretendia dar uma resposta às doutrinas do comunismo (MARTINA, 1997, p. 53-54).

A Quadragesimo Anno, encíclica do Papa Pio XI, pretendeu fazer um claro chamado à ação concreta a partir da Rerum novarum. Nela, o papa exaltou o 
modelo de corporação sindical que reunia patrões e empregados e condenou a luta de classe marxista; vai mais além que a Rerum novarum defendendo o direito do operário a um salário não só individual, mas familiar; considerou a possibilidade de superação do contrato salarial substituindo pela co-gestão; sublinhou o perigo dos monopólios que levam a ditadura econômica; confirmou a necessidade de substituir o estímulo incontrolado da livre concorrência pelo do bem comum; e admoestou a frear a ingerência do Estado totalitário na economia. Outras encíclicas importantes sobre a questão social foram a Mater et Magistra (1961) do Papa João XXIII e a Populorum progressio (1967) do Papa Paulo VI (MARTINA, 1997, p. 63-64). Estas encíclicas sociais, principalmente as duas primeiras citadas, forjaram o pensamento e o apostolado social de Irmã Dulce (ROCHA, 2019, p. 63-66).

Dois importantes eventos marcam o contexto eclesial: em âmbito universal, a celebração do Concílio Vaticano II (1962-1965) e, em âmbito LatinoAmericano, a celebração da II Conferência Geral do Episcopado Latino-Americano celebrada em Medellín-Colômbia (1968). Nesta Conferência, convocada para aplicar as orientações do Concílio Vaticano II no contexto Latino-Americano, o episcopado, seguindo as orientações principalmente das Constituições Lumen Gentium e Gaudium et Spes, propôs colocar a Igreja Latino-Americana em diálogo com o mundo moderno, mas também sugeriu, indo até além ao Vaticano II, que a Igreja Latino-Americana fizesse uma opção preferencial pelos pobres (BEOZZO, 2005, p. 67).

Na Conferência de Medellín, os bispos distinguem três níveis de pobreza: a pobreza como carência dos bens deste mundo necessários para uma vida humana digna. Esse tipo de pobreza é condenável; a pobreza espiritual como abertura e confiança em Deus; e a pobreza como compromisso, assumido voluntariamente e por amor à condição dos necessitados deste mundo (DOCUMENTO DE MEDELLÍN, n. 14,4).

No contexto Latino-americano e caribenho de pobreza e miséria da maior parte de suas populações, o episcopado na Conferência de Medellín solicitou uma "igreja pobre", que "denuncia a carência injusta dos bens deste mundo e o 
pecado que a engendra"; que se "compromete com a pobreza material"; que responde "com a diligência e audácia adequadas à urgência dos tempos"; que "sente a urgência de traduzir esse espírito de pobreza em gestos, atitudes e normas, que a tornem um sinal mais lúcido e autêntico do Senhor"; que em seus esforços de evangelização vise, "preferencialmente, os setores mais pobres e necessitados". Uma Igreja onde todos os cristãos "são chamados a viver a pobreza evangélica, apesar de nem todos da mesma maneira, pois há na Igreja diversidade de vocações" (DOCUMENTO DE MEDELLín, n. 14). A partir da fé cristã, portanto, a Igreja Latino-Americana deveria posicionar-se em defesa e proteção principalmente dos mais pobres: “O Episcopado Latino-Americano não pode ficar indiferente ante as tremendas injustiças sociais existentes na América Latina, que mantêm a maioria de nossos povos numa dolorosa pobreza, que em muitos casos chega a ser miséria desumana" (DOCUMENTO DE MEDELLíN, n. 14).

A opção preferencial pelos pobres foi reafirmada nas sucessivas Conferências Gerais do Episcopado Latino-Americano e do Caribe como um compromisso irrenunciável da Igreja Latino-Americana (DOCUMENTO DE PUEBLA, n. 1134-1165; DOCUMENTO DE SANTO DOMINGO, 178-181; DOCUMENTO DE APARECIDA, n. 391-398) e desde então marcará o fazer pastoral e teológico na América Latina.

Em consonância com a Conferência de Medellín, na III Conferência Geral do Episcopado Latino-Americano e do Caribe em Puebla-México (1979) a pobreza, de uma ótica cristã, é considerada "como expressão de privação e marginalização" do que é necessário para uma vida digna e como um "modelo de vida vivido e proclamado por Jesus como bem-aventurança (LC 6,20)”. Para o episcopado em Puebla, a "opção preferencial pelos pobres tem como objetivo o anúncio de Cristo Salvador". Esta opção, diante da escandalosa disparidade social e econômica, é uma exigência que "deve levar a estabelecer uma convivência humana digna e a construir uma sociedade justa e livre" (DOCUMENTO DE PUEBLA, n. 1148-1154).

Na IV Conferência Geral do Episcopado Latino-Americano e do Caribe em Santo Domingo-República Dominicana (1992), diante das possíveis distorções na 
compreensão da opção preferencial pelos pobres, se explicitou que esta opção não é nem exclusiva e nem excludente, já que "a mensagem da salvação está destinada a todos" (DOCUMENTO DE SANTO DOMINGO, n. 16.178).

Na V Conferência Geral do Episcopado Latino-Americano e do Caribe em Aparecida-Brasil (2007) a opção preferencial pelos pobres foi considerada como "uma das peculiaridades que marca a fisionomia da Igreja Latino-Americana e Caribenha" (DOCUMENTO DE APARECIDA, n. 391-392) e o episcopado se comprometeu a trabalhar para que a

Igreja Latino-americana e Caribenha continue sendo, com maior afinco, companheira de caminho de nossos irmãos mais pobres, inclusive até o martírio. Hoje queremos ratificar e potencializar a opção preferencial pelos pobres feita nas Conferências anteriores. Que sendo preferencial implique que deva atravessar todas nossas estruturas e prioridades pastorais. A Igreja Latino-americana é chamada a ser sacramento de amor, de solidariedade e de justiça entre nossos povos (DOCUMENTO DE APARECIDA, n. 396).

No âmbito destas Conferências, motivados pelas orientações do Concílio Vaticano II e interpelados pelo contexto de pobreza e miséria dos povos LatinoAmericanos e Caribenhos, o episcopado esclareceu progressivamente a perspectiva teológica da opção preferencial pelos pobres.

Segundo os bispos reunidos na Conferência de Santo Domingo, a opção preferencial pelos pobres tem seu fundamento na "Palavra de Deus e não em critérios retirados das ciências humanas". Para uma autêntica promoção humana, para uma verdadeira libertação integral e uma opção preferencial pelos pobres, é necessário, segundo o episcopado nesta Conferência, partir dos "fundamentos da dignidade da pessoa humana e do ambiente em que ela deve desenvolver-se, de acordo com o projeto do Criador" (DOCUMENTO DE SANTO DOMINGO, n. 16). Esta opção preferencial pelos pobres, segundo o Papa Francisco, "é mais uma categoria teológica que cultural, sociológica, política ou filosófica" (EVANGELII GAUDIUM, n. 198). Nas Sagradas Escrituras, os pobres ocupam lugar preferencial no coração de Deus. Aos que sofriam por causa da pobreza, Jesus assegurou que "Bem-aventurados vós, os pobres, porque vosso é o Reino de Deus" (Lc 6, 20). 0 
próprio Jesus se identificou com os pobres: "Tive fome e me destes de comer" (Mt 25, 34-40) (EVANGELII GAUDIUM, n. 197).

Para os bispos reunidos na Conferência de Aparecida, a "opção preferencial pelos pobres nasce da fé em Jesus Cristo, o Deus feito homem, que se fez nosso irmão (Hb 2,11-12)". Citando o discurso de Bento XVI na seção inaugural desta Conferência, os bispos na Conferência de Aparecida afirmaram que "a opção preferencial pelos pobres está implícita na fé cristológica naquele Deus que se fez pobre por nós, para nos enriquecer com sua pobreza" (DOCUMENTO DE APARECIDA, n. 392). São, pois, a predileção de Deus pelos pobres e a fé em Jesus que inspiram a Igreja a fazer uma opção preferencial pelos pobres (EVANGELII GAUDIUM, n. 198). Esta opção é entendida como

uma forma especial de primado na prática da caridade cristã, testemunhada por toda a Tradição da Igreja. Ela concerne a vida de cada cristão, enquanto deve ser imitação da vida de Cristo; mas aplica-se igualmente às nossas responsabilidades sociais (SOLLICITUDO REI SOCIALIS, n. 41).

Afirmar que a opção preferencial pelos pobres está implícita na fé cristológica tem consequências importantes para a vida do cristão e da Igreja. "Esta opção convoca os cristãos a contemplar no rosto sofredor do irmão, o rosto de Cristo que o chama a servi-Io" (DOCUMENTO DE APARECIDA, n. 393). O rosto sofredor do pobre é, pois, o rosto sofredor de Cristo. "Tudo o que tenha relação com Cristo, tem relação com os pobres e tudo o que está relacionado com os pobres reivindica a Jesus Cristo: 'cada vez que o fizestes a um desses meus irmãos mais pequeninos, a mim o fizestes' (Mt 25,40)" (DOCUMENTO DE APARECIDA, n. 393). Descobrir nos rostos sofredores dos pobres o rosto do Senhor (Mt 25,31-46) é um desafio que exige do cristão uma profunda conversão pessoal e eclesial (DOCUMENTO DE SANTO DOMINGO, n. 178).

De quem são os rostos sofredores e desfigurados nos quais o cristão, a partir da fé, é chamado a descobrir o rosto do Senhor e a servi-los? O episcopado Latino-Americano na Conferência de Santo Domingo, além de identificar os rostos dos sofredores, também aponta as causas geradoras do sofrimento. 
Na fé encontramos os rostos desfigurados pela fome, consequência da inflação, da dívida externa e das injustiças sociais; os rostos desiludidos pelos políticos que prometem, mas não cumprem; os rostos humilhados por causa de sua própria cultura, que não é respeitada, quando não desprezada; os rostos angustiados dos menores abandonados que caminham por nossas ruas e dormem sob nossas pontes; os rostos sofridos das mulheres humilhadas e desprezadas; os rostos cansados dos migrantes que não encontram digna acolhida; os rostos envelhecidos pelo tempo e pelo trabalho dos que não têm o mínimo para sobreviver dignamente (DOCUMENTO DE SANTO DOMINGO, n. 178).

Da fé em Cristo surge a caridade e a solidariedade como encontro, irmandade e serviço para com os aflitos e marginalizados. A opção preferencial pelos pobres não pode permanecer somente num plano teórico e emotivo, sem uma verdadeira incidência nas decisões e nos comportamentos. Para o episcopado Latino-Americano, esta opção, à luz da fé, deve "se manifestar em opções e gestos visíveis, principalmente na defesa da vida e dos direitos dos mais vulneráveis e excluídos, e no permanente acompanhamento em seus esforços por serem sujeitos de mudança e de transformação de sua situação" (DOCUMENTO DE APARECIDA, n. 394).

Diante das graves desigualdades atuais, nas quais muitas pessoas são descartadas e privadas dos direitos fundamentais, o Papa Francisco afirma que

o princípio do bem comum torna-se imediatamente, como consequência lógica e inevitável, um apelo à solidariedade e uma opção preferencial pelos mais pobres. Esta opção implica tirar as consequências do destino comum dos bens da terra, mas exige acima de tudo contemplar a imensa dignidade do pobre à luz das mais profundas convicções de fé. Basta observar a realidade para compreender que, hoje, esta opção é uma exigência ética fundamental para a efetiva realização do bem comum" (LAUDATO SI', n. 158).

A opção preferencial pelos pobres é, pois, na ótica do Papa Francisco, uma exigência para o bem comum e para a dignidade dos pobres; é uma exigência ética e evangélica para a concreta e efetiva realização do bem comum e, portanto, para a paz e para a fraternidade e a amizade social.

A Conferência Nacional dos Bispos do Brasil (CNBB), orientada pelos documentos do Concílio Vaticano II e pelos quatro documentos conclusivos das Conferências Gerais do Episcopado Latino-Americano e do Caribe, nos seus 
projetos de evangelização assumiu a perspectiva teológica e pastoral da opção preferencial e evangélica pelos pobres. Esta perspectiva é evidente, por exemplo, na última Diretrizes da Ação Evangelizadora da Igreja no Brasil (DGAE) 2019-2023, na qual o episcopado brasileiro, citando o documento conclusivo da Conferência de Aparecida, enfatiza que "A opção preferencial pelos pobres está implícita na fé cristológica naquele Deus que se fez pobre por nós, para nos enriquecer com a sua pobreza", para uma "Igreja pobre para os pobres" e "casa dos pobres" (DGAE 2019-2023, n. 108). Para os bispos brasileiros, "Contemplar o Cristo sofredor na pessoa dos pobres significa comprometer-se com todos os que sofrem, buscando compreender as causas de seus flagelos" (DGAE 2019-2023, n. 110). Nas DGAE 2019-2023, um dos eixos para a evangelização no Brasil é a opção preferencial e evangélica pelos pobres.

Vale ressaltar que até mesmo antes da Conferência de Medellín alguns bispos como Dom Helder Câmara, brasileiro, Dom Manuel Larraín, chileno, Dom Oscar Romero, salvadorenho, já estavam indo ao encontro das realidades de pobrezas nas periferias de suas dioceses. Até mesmo antes da Conferência de Medellín, a opção preferencial pelos pobres já era a opção de Irmã Dulce. Deste modo, podemos afirmar que o apostolado concreto e radical de amor e serviço aos pobres da freira baiana iluminou a opção preferencial pelos pobres feita pelo episcopado Latino-Americano em Medellín e colaborou concretamente para consolidar o caminho de conversão e compromisso da Igreja brasileira para com os pobres, cuja perspectiva está presente nas orientações da CNBB. Por outra parte, as decisões e orientações da Conferência de Medellín confirmaram e apoiaram a opção e missão de Irmã Dulce quando declarou: “Expressamos nosso desejo de estar sempre bem perto dos que trabalham no abnegado apostolado dos pobres, para que sintam nosso estímulo e saibam que não ouviremos vozes interessadas em denegrir seu trabalho" (DOCUMENTO DE MEDELLín, n. 14,2). A confirmação e esclarecimentos da opção preferencial e evangélica pelos pobres na Conferência de Puebla e sua recepção nos projetos de evangelização da CNBB contribuíram para orientar, ratificar e apoiar o apostolado da freira baiana. 
Irmã Dulce viveu a pobreza espiritual como abertura e confiança em Deus, viveu voluntariamente uma vida simples e pobre e lutou contra a pobreza entendida como a falta dos bens necessários para uma vida digna. De fato, toda sua vida foi uma luta contra a pobreza que desumaniza as pessoas. Ela confiava totalmente em Deus, pois doou toda sua vida a Deus e confiou suas obras à Providência Divina. Ela assumiu uma vida radicalmente pobre por amor aos necessitados e como forma de testemunho contra o mal.

A opção preferencial pelos pobres para Irmã Dulce significou simplesmente a total e radical doação de sua própria vida a serviço dos mais necessitados. Quem era o pobre para Irmã Dulce? Era essencialmente aquele desprovido dos meios básicos e necessários para suprir sua existência, principalmente as crianças e adolescentes abandonados e idosos doentes sem assistência.

\section{Amar e servir aos pobres: espiritualidade e apostolado do anjo bom da Bahia}

Amar e servir os pobres foi o ideal de vida de Irmã Dulce. Ao longo de sua vida ela soube viver de modo concreto e radical este ideal.

Quais são as influências e fontes de inspiração de Irmã Dulce? A primeira influência na religiosidade da adolescente Maria Rita vem do seio da própria família. No âmbito da caridade, o pai, Augusto Lopes Pontes, um renomado odontologista, atendia gratuitamente as pessoas que não podiam pagar um tratamento dentário. Ele foi decerto um exemplo para a filha. Ele, depois de ter inicialmente resistido à ideia da filha de ser freira, tornou-se um dos incansáveis apoiadores, materialmente e moralmente, das obras sociais da filha freira (PASSARELLI, 2019, p. 16).

Outra influência significativa na religiosidade de Maria Rita veio da tia Maria Magdalena. Magdalena integrava o Apostolado do Coração de Jesus, cujos membros se dedicavam ao trabalho social, arrecadando donativos e distribuindo roupas e comida em bairros pobres de Salvador. As premissas para participar do 
Apostolado do Coração de Jesus eram a ação e a oração. Estes dois elementos são como as duas colunas da vida religiosa de Irmã Dulce (ROCHA, 2019, p. 29-31). Em uma de suas visitas ao bairro do Tororó, em 1927, Magdalena levou a adolescente Maria Rita. Este foi o primeiro contato de Maria Rita com a pobreza e a miséria de pessoas que viviam em situação de rua, experiência esta que marcaria e mudaria a vida da adolescente. A partir deste momento, a adolescente passaria a recolher donativos para distribuí-los aos mais necessitados. Já neste período, com 13 anos, Maria Rita manifestou sua intenção de ser freira: "Eu tinha um desejo ardente de ser freira. Como nesse tempo eu era muito jovem, a Superiora declarou-me que iria fazer o possível a fim de eu poder entrar para o Convento com a idade que tinha. Motivos diversos impediram a minha entrada" (ROCHA, 2019, p. 31).

Maria Rita também herdou da família a devoção a Santo Antônio. E de fato, em todas suas obras encontramos dedicação a Santo Antônio. Em 1987, ela mesma confessou seu carinho e devoção pelo santo:

Quando tinha seis anos, fui fazer a primeira prova para entrar na escola primária e tinha medo de não passar. Minha tia me sugeriu pedir a ajuda de Santo Antônio. Fui a uma capelinha que havia perto de casa e prometi, caso conseguisse me sair bem na prova, oferecer-Ihe um maço de velas. Santo Antônio ajudou-me e, a partir daquela vez, me apeguei a ele; por isso, quando comecei esta obra, dei a ela o nome do santo. Sou devota de Santo Antônio. Sei que ele consegue o que pedimos junto a Deus (MARIA, 2019, p. 46).

Frei Hildebrando Kruthaup também exercitou uma forte influência na vida de Maria Rita. Confessor, guia espiritual e colaborador no apostolado, o Frei ensinou à jovem Maria Rita a espiritualidade de São Francisco e colaborou decididamente para seu ingresso na Congregação das Irmãs Missionárias da Imaculada Conceição da Mãe de Deus, um ramo feminino do franciscanismo (ROCHA, 2019, 33-36.40). Decerto, esta não foi uma escolha aleatória e contou com os conselhos do Frei Hildebrando Kruthaup. Portanto, Maria Rita bebeu da espiritualidade franciscana, o que se evidencia no seu estilo de vida austero, simples, alegre e pobre. 
No período do postulantado e noviciado, dois textos chamaram muito a atenção de Maria Rita: A história de uma alma de Teresa de Lisieux (1873-1897) e A imitação de Cristo de Tomás de Kempis (1380-1471). A história e o exemplo de Teresa de Lisieux, com sua simplicidade interior e a intensa vida de oração para acolher integralmente a vontade de Deus, fascinou Maria Rita. Segundo Graciliano Rocha, A imitação de Cristo serviu como uma introdução à vida que Maria Rita levaria de agora em diante como religiosa. Este texto sublinha a índole falha da natureza humana e ensina que a comunhão total com Deus só pode ser alcançada através da oração, da penitência e de uma vida santa. Estes elementos estão na base da espiritualidade de Irmã Dulce (ROCHA, 2019, p. 48-49).

O interesse e a preocupação de Irmã Dulce pelos pobres tiveram origem também na sua grande capacidade de empatia pelo sofrimento, necessidade, angústia e esperança dos excluídos da sociedade e na sua capacidade de imersão na realidade que a rodeava. É, pois, desta sua capacidade de sentir compaixão e de encarnar-se na realidade que surgiu e desenvolveu-se seu apostolado de amor e serviço aos pobres.

A capacidade de sentir compaixão pelo marginalizado e de inserção nas periferias sociais levou Irmã Dulce a comprometer-se cada vez mais pelos miseráveis: sua missão evangelizadora comprometeu-se e sua espiritualidade amadureceu do viver entre a miséria dos vulneráveis, dos clamores dos pobres abandonados pelas ruas e favelas de Salvador. Ela ouviu o clamor de um jovem que, tremendo de febre, clamava: "Irmã, não me deixe morrer na rua" (ROCHA, 2019, p. 67). Ela soube ver e discernir os "sinais dos tempos", entendendo que havia sido chamada por Deus para a missão de defesa e cuidado dos pobres. É, portanto, uma vocação e missão que nasceu, desenvolveu-se, amadureceu e nutriu-se de sua imersão na realidade sofrida do povo.

Irmã Dulce não estava interessada em discussão teórica e ideológica sobre a pobreza: "O importante é fazer a caridade, não falar da caridade" (PASSARELLI, 2019, p. 182), afirmou a freira baiana. Quando se tratava de socorrer e ajudar os pobres e doentes, suas medidas eram muito concretas e propositivas, como a de 
arrombar casas abandonadas para alojar os doentes sem assistência (ROCHA, 2019, p. 67-70). Sua luta incansável era defender a vida, salvar a vida do indigente.

O apostolado social de Irmã Dulce, prático e ausente de tendências político-partidárias, visava atender imediatamente às necessidades mais urgentes dos doentes sem assistência e das crianças e jovens em situação de rua; aspirava criar estruturas que transformassem as vidas dos pobres, doentes e descartados, restituindo-Ihes a dignidade perdida. Nesta missão, o importante para a freira baiana era o amor, era dar a oportunidade para que as pessoas melhorassem de vida.

O importante é o amor, a caridade. Não apenas a esmola, mas a caridade de uma pessoa pela outra, sem distinções. A esmola ajuda a resolver o problema em parte, mas todos devem se ajudar reciprocamente. Aqui no nosso centro não nos limitamos a dar esmolas: nos esforçamos para dar às pessoas a possibilidade de melhorarem de vida (PASSARELLI, 2019, p. 183).

O caráter caritativo da atividade de Irmã Dulce não significava uma visão superficial da miséria de tantos seres humanos. Para ela, a miséria é fruto do egoísmo humano, da falta de amor entre as pessoas; a pobreza não é apenas um problema individual, mas também estrutural.

Miséria é falta de amor entre os homens. Deus não gosta dos insensíveis. O problema é estrutural, pois as pessoas, individualmente, ajudam, como fizeram até hoje comigo. Eu não entro na área política, não tenho tempo para me ocupar com as implicações partidárias. O meu partido é a pobreza. Eu só não gosto quando usam o meu nome para conquistar simpatias. Isto prejudica o meu trabalho (PASSARELLI, 2019, p. 116).

A miséria de tantos seres humanos não é, pois, produzida pela vontade de Deus ou pela força da natureza, mas é resultado do egoísmo humano, da falta de solidariedade e de um projeto de sociedade excludente.

A atividade social de Irmã Dulce de amor e serviço aos pobres foi um grande apelo à indiferença da sociedade em geral, mas também à própria Igreja Católica ou pelo menos a setores da Igreja Católica, diante do escândalo da miséria de muitos seres humanos. Frente aos rostos desfigurados pela dor e pela 
miséria não havia espaço para a apatia no coração de Irmã Dulce. Para ela, a indiferença era a negação da humanidade, a negação da imagem e semelhança de Deus. Crentes e não crentes que conheceram Irmã Dulce e sua obra se sentiram interpelados a serem mais solidários.

A ação social de Irmã Dulce colocou-se principalmente no âmbito da caridade, da promoção da dignidade do pobre. Ela não fez uma denúncia pública e verbal das estruturas geradoras e mantenedoras da pobreza. Sua denúncia da injustiça social expressou-se mais explicitamente no âmbito do seu testemunho, ou seja, a partir de sua vida e de seu operar em defesa e cuidado dos mais necessitados. Em uma entrevista ao Jornal da Bahia em 15 de agosto de 1971 ela declarava: "Prefiro trabalhar em silêncio. $O$ importante é fazer a caridade, não falar da caridade" (PASSARELLI, 2019, p. 182).

Em sua árdua missão em favor dos pobres, a freira baiana se dedicava pessoalmente no trabalho de angariar recursos para manter seus empreendimentos sociais, trabalho este fundamental, haja vista a progressiva ampliação do projeto social da religiosa. Para tanto, ela mesma saía batendo na porta de governantes, empresários, comerciantes, feirantes etc. pedindo esmola: “o que você pode dar para os meus doentes?”. Ela recorria à ajuda de todos e não recusava a ajuda de ninguém. $E$ de fato, ela conseguiu incrementar e sustentar suas obras sociais graças à caridade do povo baiano, de artistas, empresários, políticos e de instituições nacionais e internacionais 4 .

Diante de uma intensa atividade social, Irmã Dulce não descuidou da oração. Ela encontrou o tempo para rezar. Podemos dizer que a força que a impeliu e a sustentou nos seus esforços gigantescos foi a oração. Esta oração nasce da convicção de estar fazendo a vontade de Deus e que tudo o que fazia era obra de Deus. A importância da oração é patente em sua fala:

Nós não podemos conseguir nada se nós não fizermos da nossa vida uma oração contínua. Eu socorro a Ele sem interrupção. Afinal de contas, somos humanos,

\footnotetext{
${ }^{4}$ Entre os benfeitores mais famosos das obras sociais de Irmã Dulce estão o empresário Norberto Odebrecht, o bancário Ângelo Calmôn de Sá e os políticos Antônio Carlos Magalhães e José Sarney (ROCHA, 2019, p. 33). 
ainda não somos anjos. A oração é que faz tudo, a ação é decorrente da oração. Nós não podemos nos dedicar à ação sem a oração, porque seria tudo perdido, não seria uma coisa de Deus. O que nós temos conseguido aqui é somente pela oração (ROCHA, 2019, p. 92).

Em outra fala de Irmã Dulce fica bem enfatizada a oração como inspiração e sustentáculo da ação:

Toda a nossa força está na oração. Sem ela, não podemos fazer nada. É por intermédio da oração que obtemos de Deus as graças necessárias para executar bem a nossa missão entre os pobres. Somos criaturas humanas, frágeis e sujeitas às tentações. Através da oração, Deus nos transmite todas as graças de que necessitamos para levar a cabo o nosso trabalho de amor e de dedicação, sem reservas, aos nossos irmãos sofredores, os pobres. A oração é o alimento da nossa alma, não podemos viver sem rezar [...] (PASSARELLI, 2019, p. 130).

Não obstante as dificuldades, os sofrimentos e as humilhações morais advindas de sua missão em defesa e cuidado dos mais pobres e doentes, Irmã Dulce era feliz. A origem de sua felicidade vem da certeza de estar agindo de acordo com a vontade de Deus, de estar vivendo as bem-aventuranças (Mt 5, 56.9-12).

A alegria e serenidade de Irmã Dulce diante das dificuldades vem de sua profunda fé na Providência Divina. Ela entendia que as obras sociais não eram suas, mas de Deus. Ela entregava tudo a Deus e Nele tudo confiava. Falando do grande trabalho com os doentes ela afirmava:

Não é Irmã Dulce que faz nada, e a gente tem uma prova diária e real que é o dedo de Deus que trabalha aqui dentro, que é a Providência Divina. Temos 930 doentes aqui dentro e não falta nada, do remédio mais caro à substância mais barata, nem alimentação, nem cuidado médico, nem os exames [...] (ROCHA, 2019, p. 49).

Para ela, a oração e a confiança em Deus não significavam atitude passiva de espera que as coisas acontecessem ou caíssem do céu. Sua oração era sempre acompanhada da ação. 


\section{O pobre é a imagem de Cristo}

A opção preferencial pelos pobres de Irmã Dulce é uma opção evangélica, que deriva de sua fé em Cristo. Ela compreendeu que o amor pelos pobres e excluídos está no centro do evangelho. A opção preferencial pelos doentes, cegos, pecadores e prostitutas é uma opção de Jesus Cristo (Mt 14, 14; Mc 10, 4652; Mc 2, 16; LC 7, 36-50). Além disso, segundo a ótica evangélica, acolher e cuidar do necessitado é acolher e cuidar do próprio Cristo presente no rosto do pobre: "Em verdade vos digo: cada vez que o fizestes a um desses meus irmãos mais pequeninos, a mim o fizestes. [...] Em verdade vos digo: todas as vezes que o deixastes de fazer a um desses mais pequeninos, foi a mim que o deixastes de fazer" (Mt 25, 39.45).

Toda a vida de Jesus, com suas palavras, sua forma de tratar os pobres e marginalizados, seus gestos concretos, sua generosidade e sua coerência de vida, marcou e plasmou a vida interior e o apostolado social de Irmã Dulce. A vida e a obra de Irmã Dulce nos permitem captar um aspecto fundamental e profundo de sua espiritualidade: o pobre é a imagem de Cristo. No rosto do pobre, sofredor e chagado, Irmã Dulce viu o Cristo chagado e sofredor. Por este motivo ela dedicou totalmente e radicalmente sua existência aos pobres, aos abandonados e doentes sem assistência. A freira era movida pelo amor a Cristo sofredor presente nos mais carentes e necessitados. Questionada por ter arrombado casas abandonadas para colocar doentes, Irmã Dulce explicou a motivação de sua ação:

Muita gente acredita que não devemos dar aos pobres a mesma atenção que damos às outras pessoas. Para mim, o pobre, o doente, aquele que sofre, o abandonado, é a imagem de Cristo [...]. Se virmos o pobre com esses olhos, o seu exterior, o estar sujo, cheio de parasitas, com grandes chagas, não nos incomodará, pois na sua pessoa está presente o Cristo sofredor. Somente quem convive com o pobre pode compreendê-lo. Muita gente pensa que faço muito, que concedo muita atenção aos pobres, e me criticam por isso. Cada um de nós não gostaria de ser bem recebido, de ser bem tratado? E o pobre não possui o direito de ser bem acolhido, de receber todas as atenções espirituais e materiais? [...] Fazemos muito por eles? Eu pergunto: é muito o que fazemos por Deus? Ele não merece tudo de nós? Se o pobre representa a imagem de Deus - Estava nu e me vestiste, doente e 
me visitaste, com fome e me deste de comer (Mt 25, 35-36) -, então, pode ser demais aquilo que fazemos pelos pobres? (PASSARELLI, 2019, p. 94).

Coerente com a perspectiva teológica e pastoral da opção preferencial e evangélica pelos pobres das Conferências Gerais de Medellín (1968) e de Puebla (1979), na mística dulciana Deus se manifesta preferencialmente nas periferias sociais e existenciais e é por isso que ela está presente nestas periferias (ROSSI, 2019, p. 9). Ela se encontrava com Cristo sofredor presente no rosto da criança abandonada e do idoso doente sem assistência. Encontrar a Cristo significava encontrar o pobre que sofre e encontrar o pobre significava encontrar a Cristo. Deste modo, portanto, podemos afirmar que o fundamento de seu apostolado está no seu amor a Cristo sofredor. A espiritualidade dulciana é essencialmente cristólogica, assim como seu humanismo é cristológico.

Da compreensão de que o pobre é a imagem de Cristo, Irmã Dulce tira outra consequência: todo serviço ao pobre é serviço a Deus. Por isso, o serviço ao pobre, que é um serviço a Deus, nunca é demais; por mais que se faça, sempre é pouco diante daquilo que Deus fez e faz por nós.

O Jesus que Irmã Dulce ama, segue e imita é o Jesus que é solidário, que acolhe os doentes, as crianças, os impuros, os pecadores, as mulheres, os excluídos e invisíveis do seu tempo. E são exatamente os pobres, presos, cegos e oprimidos os alvos da missão de Jesus (LC 4, 18-19). Como discípula e missionária de Jesus, Irmã Dulce foi uma continuadora dessa missão. Ela compreendeu que sua missão era em favor e solidariedade dos mais necessitados porque esta também foi a missão de Jesus.

O pensamento e a preocupação pelo pobre é uma realidade presente na Sagrada Escritura e na prática da vida eclesial. A compreensão de que o pobre é a imagem de Cristo não foi, pois, uma novidade em Irmã Dulce. Seu maior mérito, num contexto Latino-Americano e brasileiro marcado pela pobreza e miséria da maior parte de suas populações, foi o de relembrar, com atitudes e gestos concretos, aos cristãos e à Igreja que o pobre é a imagem de Cristo; que Cristo está presente no rosto do pobre; e que o pobre deve ser preferencialmente cuidado e promovido espiritualmente e materialmente. 
A mística do Cristo presente no pobre foi muito bem expressada por João Crisóstomo (349-407). Este pai da Igreja, bispo de Constantinopla, falando da Eucaristia e tendo presente a vida de opulência de poucas pessoas e a miséria de muitas, chamou a atenção dos cristãos sobre a necessidade de socorrer os pobres. Assim exortava João Crisóstomo:

Vocês realmente querem honrar o corpo de Cristo? Não permitam que ele fique nu. Não o honrem aqui com roupas de seda e lá fora o deixem morrer de frio e nudez. [...] O sacramento não precisa de toalhas preciosas, mas de uma alma pura; os pobres, no entanto, requerem muito cuidado (SAN JUAN CRISÓSTOMO, Homilia 50, p. 653-654).

João Crisóstomo não pretendia inculcar nos cristãos o descuido para com o culto divino, mas demonstrar o que realmente e verdadeiramente é prioridade no apostolado do cristão: o cuidado para com os pobres. A motivação fundamental desta prioridade está no ser o pobre o outro Cristo. Assim, continua Crisóstomo:

Qual a utilidade de a mesa de Cristo estar cheia de vasos de ouro, enquanto Ele está morrendo de fome? Primeiro sacie o faminto e depois, com o que sobra, decore sua mesa também. Você faz um cálice de ouro e não lhe dá um copo de água fria? E que necessidade há de decorar o altar com panos bordados de ouro e, em vez disso, não dar a Cristo até mesmo o abrigo necessário? Que utilidade há nisso? Diga-me, com efeito: se você vendo um infeliz sem o sustento necessário, o deixasse faminto e se dedicasse a cobrir a mesa com ouro, será que ele the agradeceria o benefício ou ficaria mais irritado contra você? E se, ao vê-lo vestido em trapos e gelado de frio, você não lhe estendesse um vestido e, em vez disso, se entretivesse em erguer colunas de ouro, dizendo-lhe que tudo isso foi feito em sua homenagem? Não diria ele que estar zombando e insultando? Pois pensa tudo isto sobre Cristo. Ele está errante e peregrino, precisando de teto; e você, que não $O$ acolhe, se diverte em adornar o pavimento, as paredes e os capitéis das colunas, e em pendurar lâmpadas com correntes de ouro. No entanto, você não quer vê-Lo acorrentado nas prisões. Falando assim, repito, não é que proíba um esforço de ser feito na decoração da igreja; o que exorto é que junto com isso, ou antes, antes, se busque a ajuda dos pobres. [...] Ao decorar a casa, então, não abandone seu irmão na tribulação, pois ele é um templo mais precioso do que o outro (SAN JUAN CRISÓSTOMO, Homilia 50, p. 654-655). 
A força e a eloquência das palavras de João Crisóstomo nos lembram a força e a eloquência da ação caritativa de Irmã Dulce em defesa e cuidado dos mais vulneráveis. A força de ânimo de Irmã Dulce, seu exemplo de amor e serviço, conquistava até mesmo os mais duros corações para sua causa humanitária. Seu exemplo e carisma estimulava um espírito de generosidade e solidariedade nas pessoas. Crisóstomo (boca de ouro) era famoso por sua eloquência no falar. Já Irmã Dulce era famosa e conhecida por seu exemplo de amor, caridade e serviço encarnado.

\section{Irmã Dulce: a boa samaritana da Bahia}

Em uma leitura atenta e comparada entre a parábola bíblica do bom samaritano (LC 10, 25-37) e a vida e a atividade social de freira baiana, podemos encontrar muitos aspectos similares, de maneira que podemos dizer que Irmã Dulce foi a boa samaritana da Bahia. Ela foi uma boa samaritana pelas ruas de Salvador. Ela jamais passou ao largo de um caído no chão, olhou e seguiu adiante, como fez o sacerdote e o levita (LC 10, 21-32). Diante de uma criança abandonada nas ruas, de um idoso chagado e caído sem assistência, ela sentia compaixão, parava, acolhia e o levava para um abrigo para cuidá-lo. Seu tempo era todo dedicado aos pobres. Nenhum compromisso a desviava do caminho dos mais necessitados. Sua missão incansável era levantar o caído, cuidá-lo e incluí-lo na sociedade, pois, toda forma de exclusão é antievangélica e negação do Reino de Deus.

Para alguns judeus da época de Jesus um samaritano era considerado um sujeito impuro e desprezível. Não obstante, o samaritano se aproximou, sentiu compaixão e cuidou das chagas do judeu caído (LC 10, 34). Assim como o bom samaritano, Irmã Dulce no seu apostolado não fazia distinção das pessoas por motivos religiosos, étnicos e sociais. Seu amor e serviço abraçava a todos indistintamente. Ela se tornava próxima e presente de todos que necessitavam de ajuda. 
O samaritano precisou da ajuda do hospedeiro para cuidar do judeu ferido (LC 10, 35). Irmã Dulce era consciente de que não podia fazer tudo sozinha. Ela soube engajar e estimular as pessoas a participarem no compromisso de amor e cuidado ao pobre. O amor e serviço do Anjo bom da Bahia para com os mais necessitados contagiava todos que conheciam a sua vida e missão e por isso ela tinha uma enorme facilidade em recrutar colaboradores para sua obra humanitária e angariar recursos para o serviço de solidariedade em defesa da vida.

Na narração bíblica, não sabemos nada sobre o bom samaritano, nem mesmo seu próprio nome. Ele não esperava reconhecimento. Assim como o bom samaritano, Irmã Dulce também não esperava nada em troca pelo seu serviço de ajuda e cuidado ao pobre. Ela preferia que as obras falassem por si só. Sua missão era um serviço de amor aos mais necessitados, imagem do Cristo sofredor, e seu interesse era o de levantar o caído, dar dignidade e esperança aos mais vulneráveis e descartados da sociedade.

\section{Considerações finais}

Irmã Dulce é santa porque viveu radicalmente e exemplarmente o amor (ágape) e o serviço (diakonia) de modo preferencial pelos pobres: crianças, jovens e doentes sem assistência, abandonados nas periferias sociais.

Hoje, que provocações e ensinamentos podemos tirar da opção preferencial pelos pobres em Santa Dulce?

A opção preferencial pelos pobres em Santa Dulce nos lembra que esta opção nasce da fé em Jesus Cristo, o Deus feito homem, que se fez nosso irmão (cf. Hb 2,11-12).

A opção preferencial pelos pobres em Santa Dulce nos provoca a descobrir e contemplar no rosto do pobre sofredor o rosto do Cristo sofredor e a cuidar do pobre, o outro Cristo.

A opção preferencial pelos pobres em Santa Dulce nos estimula a romper com a indiferença. Em Santa Dulce, a fé em Deus implica responsabilidade e 
cuidado para com o outro, principalmente os mais vulneráveis; a abertura do coração aos irmãos é uma garantia de uma autêntica abertura a Deus.

A opção preferencial pelos pobres em Santa Dulce nos incita a romper as barreiras do preconceito religioso, étnico e social. O amor e serviço de Santa Dulce abraçou a todos e com todos colaborou a fim de ajudar os pobres excluídos à margem da sociedade. Ela é um exemplo concreto do ecumenismo e do diálogo inter-religioso de cooperação.

A opção preferencial pelos pobres em Santa Dulce é um estímulo a uma “Igreja em saída". Os pobres vinham até Irmã Dulce, porém, ela era a primeira a sair pelas ruas em busca dos descartados da sociedade. Como o bom samaritano, ela se aproxima dos caídos, das crianças e doentes abandonados; ela até os procura pelas ruas de Salvador para cuidar e resgatar sua humanidade e dignidade. Ela é um exemplo de proximidade e amizade social.

A opção preferencial pelos pobres em Santa Dulce nos impulsiona a procurar caminhos novos e criativos a fim de responder aos desafios e efeitos da pobreza. Irmã Dulce foi criativa e empreendedora na criação de iniciativas que cuidassem e promovessem os doentes sem assistência e crianças abandonadas.

A opção preferencial pelos pobres em Santa Dulce nos ensina que a santidade é possível e que é um caminho para todos os cristãos, pois ela sendo uma simples mulher, de saúde frágil, viveu em meio ao povo de modo exemplar e santo.

A opção preferencial pelos pobres em Santa Dulce é um extraordinário incentivo à cultura da paz, da solidariedade e da amizade social, assim como exorta Papa Francisco em sua carta encíclica Fratelli Tutti. A caridade e a solidariedade de Santa Dulce continuam ainda hoje a contagiar e a provocar a tantas mulheres e homens de boa vontade. O modo de ser e estar no mundo de Santa Dulce dos Pobres é bem expressado no poema "Não sei” de Cora Coralina (2016):

Não sei se a vida é curta

ou longa demais pra nós,

mas sei que nada do que vivemos tem sentido,

se não tocamos o coração das pessoas. 


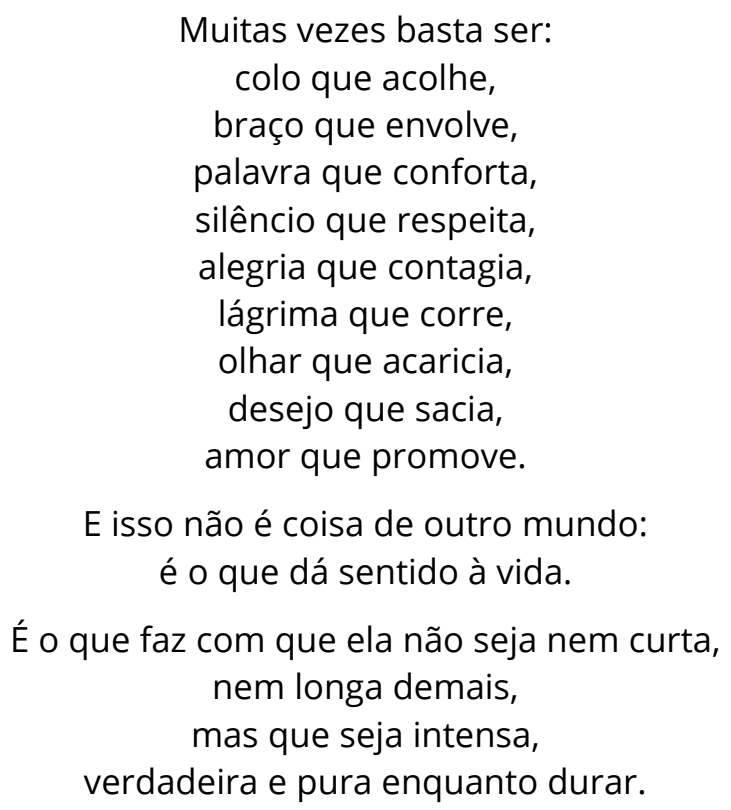

Por fim, em um mundo afogado no egoísmo, no individualismo e em uma economia que produz pobres, o exemplo concreto de solidariedade e fraternidade de Santa Dulce dos Pobres permanece ecoando em nossos ouvidos e corações e continua através do seu grande legado (das Obras Sociais Irmã Dulce) salvando vidas e resgatando a dignidade de tantos irmãos. O amor e serviço vivido por Santa Dulce dos Pobres segue produzindo obras de solidariedade. "Agora, portanto, permanecem fé, esperança, caridade, essas três coisas. A maior delas, porém, é a caridade" (1 Co 13, 13).

\section{Referências}

BEOZZO, J. O. Vaticano ll e as transformações culturais na América Latina e no Caribe. São Paulo: Paulinas, 2005.

BRUNELLI, D. Profetas do Reino: Grandes Linhas da Atual Teologia da Vida Religiosa na América Latina. São Paulo: Conferência dos Religiosos do Brasil, 1986.

CONCÍLIO VATICANO II. Constituição dogmática sobre a Igreja Lumen Gentium. Disponível em: http://www.vatican.va/archive/hist_councils/ii_vatican_council/documents/vatii_const_19641121_lumen-gentium_po.html. Acesso em: 13 abr. 2021. 
CONFERÊNCIA NACIONAL DOS BISPOS DO BRASIL. Diretrizes da Ação Evangelizadora da Igreja no Brasil (DGAE) 2019-2023. Documento da CNBB 109. Brasília-DF: Edições CNBB, 2020.

CONSELHO EPISCOPAL LATINO-AMERICANO (Celam). Documento de Aparecida. Texto conclusivo da V Conferência Geral do Episcopado Latino-Americano e do Caribe. São Paulo: Paulus, 2007.

CONSELHO EPISCOPAL LATINO-AMERICANO (Celam). Documentos do Celam: conclusões das Conferências do Rio de Janeiro, Medellín, Puebla e Santo Domingo. São Paulo: Paulus, 2005.

CORALINA, C. Não sei (poema). A Soma de todos os Afetos, abr. 2016. Disponível em: https://www.asomadetodosafetos.com/2016/04/nao-sei-cora-coralina.html. Acesso em: 15 abr. 2021.

ESCOLA BÍBLICA DE JERUSALÉM. Bíblia de Jerusalém. São Paulo: Paulus, 2002.

MARIA, K. Irmã Dulce: A Santa brasileira que fez dos pobres sua vida. São Paulo: Paulus, 2019.

MARTINA, G. História da Igreja de Lutero a nossos dias. 3. ed. São Paulo: Loyola, 1997. v. 4.

PAPA BENTO XVI. Discurso na sessão inaugural dos trabalhos da V Conferência Geral do Episcopado da América Latina e do Caribe (Santuário de Aparecida, 13 de maio de 2007). Disponível em: https://www.vatican.va/content/benedictxvi/pt/speeches/2007/may/documents/hf_ben-xvi_spe_20070513_conferenceaparecida.html. Acesso em: 09 set. 2021.

PAPA FRANCISCO. Carta Encíclica Laudato Si' (sobre o cuidado da Casa Comum). 24/05/2018. Disponível em: https:/www.vatican.va/content/francesco/pt/encyclicals/documents/papafrancesco_20150524_enciclica-laudato-si.html. Acesso em: 09 set. 2021.

PAPA FRANCISCO. Evangelii Gaudium (24 de novembro de 2013). Disponível em: https://www.vatican.va/content/francesco/pt/apost_exhortations/documents/papa-

francesco_esortazione-ap_20131124_evangelii-gaudium.html\#_ftn170. Acesso em: 09 set. 2021.

PAPA FRANCISCO. Fratelli Tutti (03 de outubro de 2020). Disponível em: https://www.vatican.va/content/francesco/pt/encyclicals/documents/papa-

francesco_20201003_enciclica-fratelli-tutti.html. Acesso em: 09 set. 2021.

PAPA JOÃO PAULO II. Sollicitudo Rei Socialis (30 de dezembro de 1987). Disponível em: https://www.vatican.va/content/john-paul-ii/pt/encyclicals/documents/hf_jp-

ii_enc_30121987_sollicitudo-rei-socialis.html. Acesso em: 12 set. 2021. 
PASSARELLI, G. Santa Dulce dos Pobres: O anjo bom do Brasil. São Paulo: Paulinas, 2019. ROCHA, G. Irmã Dulce, a santa dos pobres. São Paulo: Planeta, 2019.

ROSSI, L. A. S. Nos passos de Santa Dulce dos Pobres, o anjo bom da Bahia. São Paulo: Paulus, 2019.

SAN JUAN CRISÓSTOMO. Homilías sobre el Evangelio de San Mateo. DocerArgentina. Disponível em: https://docer.com.ar/doc/5snen. Acesso em: 18 mar. 2021. 